\title{
The Antigenotoxic Activity of Brown Seaweed (Sargassum sp.) Extract Against Total Erythrocyte and Micronuclei of Tilapia (Oreochromis niloticus) Exposed by Methomyl-Base Pesticide
}

\author{
Yuni Kilawati ${ }^{1}$, R Adharyan Islamy ${ }^{2 *}$ \\ ${ }^{1}$ Department of Aquatic Resources Management, Faculty of Fisheries and Marine Sciences, University of Brawijaya, \\ Malang, Indonesia. \\ ${ }^{2}$ Department of Aquaculture, Faculty of Fisheries and Marine Sciences, University of Brawijaya, Malang, Indonesia.
}

Abstract

Pesticides are widely applied in the agriculture sector to protect crops and pest control. The poisonous substance of pesticides will affect all of the organisms, either target and non-target organisms. Fish can play the role of an indicator of genotoxic presence in aquatic environments. Polysaccharide extracts from sargassum have promising anti-genotoxic potential. This study aimed to analyze the anti-genotoxic activity of brown seaweed (Sargassum polycystum) methanol extract against erythrocyte and micronuclei of tilapia exposed by methomyl-base pesticide. Brown seaweed (Sargassum sp.) purchased from farmers in Sumenep Regency, Madura, East Java, then macerated using methanol 1: 3 (w/v) for $3 \times 24$ hours at room temperature. The phytochemical screening was including flavonoids, alkaloids, triterpenes, saponins, and tannins. Tilapia fish $(T L \pm 9-12 \mathrm{~cm})$ purchased from the Technical Application Unit of Freshwater Fish (UPT Perikanan Air Tawar), Sumberpasir, Malang, East Java. The result of this study showed that exposure of methomylbased pesticides in the concentration of $4.015 \mathrm{ppm}$ indicates the formation of micronuclei of $318.33 \%$. The increased concentration of extract treatment is directly proportional to the decrease of micronuclei. It means that sargassum extract can reduce the genotoxic effect on exposed tilapia by methomyl-based pesticides. The best concentration of Sargassum sp. extract that can reduce genotoxic was D (200 ppm).

Keywords: Antigenotoxic, Extract, Methomyl, Pesticides, Sargassum sp., Tilapia.

\section{INTRODUCTION}

Pesticides are widely applied in the agriculture sector to protect crops and pest control [1]. Methomyl $\left(\mathrm{C}_{5} \mathrm{H}_{10} \mathrm{~N}_{2} \mathrm{O}_{2} \mathrm{~S}\right)$, S-methyl-1$\mathrm{N}$ - [(methyl carbamoyl)-oxy]-thioacetimidate, is a carbamate pesticide which widely used in many agricultural countries because of its highefficiency biological activity to control pest and protect the crops $[2,3]$. Some pesticides aimed to attack a specific group of the target, but its poisonous substance will affect all of an organism, either organism target and non-target [4]. On another side, the specific concentration of methomyl pesticides can cause acute poisoning, even death of fish [5]. A study report that methomyl pesticide caused a genotoxic effect against fish [6].

Aquatic environments are the final sink for many chemicals, including pesticides, and water can serve as the vehicle for exposure to many toxic agents [7]. Fish are the principal of aquatic animals. They can be an excellent sample for monitoring pesticide toxicity, such as methomyl in aquatic systems. It is because they are

\footnotetext{
${ }^{*}$ Correspondence address:

R Adharyan Islamy

Email : r.adhariyan@gmail.com

Address : Dept. Aquaculture, Brawijaya University, Jl. Veteran Malang No. 16, Malang, East Java 65145.
}

susceptible to pollutants, they can metabolize xenobiotics, and they relatively exhibit a very high bioaccumulation rate of dissolved chemicals [8-11].

The genotoxic effect is a change in the function of gene expression that occurs due to a bond between DNA and carcinogenic substances. It leads to the appearance of physiological changes in the body, such as chronic tissue damage, changes in the body's immune system, hormonal changes, or binding to proteins that are repressive to specific genes [12]. To overcome the genotoxic effects due to exposure to a toxin, such as pesticides, is through the administration of extracts that function as antigenotoxic effects. Several studies report that polysaccharide extracts from sargassum have promising anti-genotoxic potential and antimutagenic activity $[13,14]$. This study aimed to analyze the anti-genotoxic activity of brown seaweed (Sargassum polycystum) methanol extract against erythrocyte and micronuclei of tilapia, exposed by methomyl-base pesticide.

\section{MATERIAL AND METHOD \\ Preparation of Seaweed Extract}

Brown seaweed (Sargassum sp.) purchased from farmers in Sumenep Regency, Madura, East Java. The seaweed cleaned by using freshwater 
then shade-drying for four days. Dry seaweed then ground until seaweed powder obtained.

Total of $500 \mathrm{~g}$ seaweed powder put into a jar, then macerated using methanol 1: $3(\mathrm{w} / \mathrm{v})$ for $3 \times 24$ hours at room temperature, in three times replication. The maceration solution is then filtered using filter paper (Whatman no. 41), then filtrate and residue obtained. The filtrate then evaporated using a rotary evaporator vacuum at $40^{\circ} \mathrm{C}$ until a concentrated extract obtained then calculated the percentage of yield.

\section{Phytochemical Screening}

Phytochemical screening, including flavonoids, alkaloids, triterpenes, saponins, and tannins, followed the published methods [15].

Determination of Flavonoids: seaweed powder ( $1 \mathrm{~g}$ ) was boiled with $10 \mathrm{~mL}$ of distilled water for 5 minutes and filtered while it was hot. A few drops of $20 \%$ sodium hydroxide solution added to $1 \mathrm{~mL}$ of the cooled filtrate. A change to a yellow color, in addition to acid, changed into a colorless solution, that depicted the presence of flavonoids [15].

Determination of alkaloids: the seaweed powder (200 mg) boiled with $10 \mathrm{~mL}$ water and 10 $\mathrm{mL}$ of hydrochloric acid using a water bath. Finally, it was filtered, and its $\mathrm{pH}$ adjusted to about 6-7 with ammonia. The filtrate $(1 \mathrm{~mL})$, add with a few drops of Mayer's reagent (potassium mercuric iodide solution). Besides, a $1 \mathrm{~mL}$ portion was treated similarly with Wagner's reagent (solution of iodine in potassium iodide). Turbidity or colored precipitation with either of these reagents was taken as evidence for the presence of alkaloids [15].

Determination of triterpenes: A total of $3 \mathrm{~g}$ of seaweed powder placed into a test tube, then add $10 \mathrm{~mL}$ of $50 \%$ alcohol, heated for 3 minutes on a water bath. After that, cool at room temperature then filtered. The filtrate evaporated in an evaporating dish. Petroleum ether $(5 \mathrm{~mL})$ then added to the dish, stirred for 5 minutes. We added chloroform $10 \mathrm{~mL}$ and stirred for about 5 minutes, then transferred into a test tube, and $0.5 \mathrm{mg}$ of anhydrous sodium sulfate was added and shaken gently then filter. The filtrate was then divided into two test tubes and used for the following tests.

Liebermann-Burchard's reaction: To test tube I, an equal volume of acetic anhydride added and gently mixed. Then $1 \mathrm{~mL}$ of concentrated sulfuric acid was added down the side of the tube. The appearance of a brownish-red ring at the contact zone of the two liquids and a greenish color in the separation layer indicates the presence of sterols and triterpenes.

Salwoski's test: To test tube II, 2 to 3 drops of concentrated sulphuric acid was added to form a lower layer. The reddish-brown color at the interphase indicates the presence of a steroidal ring [15].

Test for saponins: seaweed powder $(1 \mathrm{~mL})$ was diluted with distilled water to $20 \mathrm{~mL}$ and shaken for 15 minutes in a graduated cylinder. The development of stable foam suggests the presence of saponins [15].

Test for tannins: Sample (1 g) was boiled with $20 \mathrm{ml}$ distilled water for $5 \mathrm{~min}$ in a water bath and filtered while it was hot. Then $1 \mathrm{ml}$ of cool filtrate was diluted to $5 \mathrm{ml}$ with distilled water, and a few drops $(2,3)$ of $10 \%$ ferric chloride were added and observed for the formation of precipitates and any color change. A bluish-black or brownish-green precipitate indicated the presence of tannins [15].

\section{Animal Preparation}

Tilapia fish ( $T L \pm 9-12 \mathrm{~cm}$ ) purchased from the Technical Application Unit of Freshwater Fish (UPT Perikanan Air Tawar), Sumberpasir, Malang, East Java. Fish then acclimatized in the aquarium based on published methods [6].

\section{Pesticide Preparation}

The methomyl-based pesticide purchased from the agriculture market in Batu, East Java, Indonesia, as Lannate 25 WP. The concentration of methomyl-base pesticides in this study was 4.015 ppm base on a published report [6].

\section{Treatment}

Research phase 1: Prepare the aquarium $(60 \times 30 \times 30 \mathrm{~cm})$ labeled for control (without treatment) and test (three replication each) then refill with fresh water. Acclimated tilapia fish then transferred into the prepared aquarium, ten fishes each. Dissolve methomyl-based pesticide that has been measured into each aquarium, allow up to $2 \times 24$ hours then sampling the fish blood in each aquarium.

Research phase 2: Prepare the aquarium $(60 \times 30 \times 30 \mathrm{~cm})$ labeled for test and control (three replication each) then refill with fresh water. Transfer the remaining fish gently from research phase 1 into aquarium research phase 2 then dissolve extract of sargassum (Negative Control, 25 ppm, 50 ppm, 100 ppm, 200 ppm, and positive control) modified from the published concentration [16], allow up to $2 \times 24$ hours then sampling the fish blood in each aquarium. 


\section{Data Collection \\ Total Erythrocyte Count}

The tilapia anesthetized using a benzocaine solution (1g.10L $\mathrm{L}^{-1}$ water). After immobilization, around $2.0 \mathrm{~mL}$ of blood withdrew using puncturing at the caudal peduncle, using syringes and sterilized needles. One drop of the blood sample smeared on object-glass, then air-dry and stained using Rosenfeld's procedure [17] for 10 minutes, so a blood sample preparation obtained. Erythrocyte counts performed according to a published method with an optical microscope [18]. The results obtained were subjected to analysis of variance. The $F$ values that indicated significant differences $(P<0.01)$ were subjected to the Duncan test to compare the means.

\section{Micronuclei Assay}

After 96 hours exposed by methomyl-based pesticide, erythrocyte blood from each fish group sampled and smeared on clean microscope slides. After fixation in absolute methanol for about $20 \mathrm{~min}$, the slides air-dried and stained with $10 \%$ of Giemsa for about 25 minutes. Six slides of 1,000 erythrocytes that sampled from each Tilapia (O. niloticus) scored [19], observed, and coded by using a microscope (Olympus CX21) with 400X magnification. It determined the frequency of micronucleus cell and other different patterns of morphologically altered erythrocyte and then counted as cell per 1000 (\%) [20]. The micronucleus frequency then counted base on Betancur formulation [21].

\section{Micronuclei frequency $=\frac{\text { Micronuclei } x 1000}{\text { Total Cell Counted }}$ \\ RESULT AND DISCUSSION Extract yield}

Quantification result of Sargassum extract yield at repetition 1,2 , and 3 was $9 \%, 7.22 \%$, $8.09 \%$, respectively (Table 1 ). The yield is an important parameter to determine the economic value and effectiveness of an ingredient or product. A yield is a percentage of the raw material that can be utilized. The higher the yield value of a material, the higher its economic value as well as its utilization.

Table 1. Yield extract of Sargassum sp.

\begin{tabular}{ccc}
\hline Repetitions & Yield weights (Gram) & Percentage (\%) \\
\hline $\mathbf{1}$ & $8 ., 83$ & $9.00 \%$ \\
$\mathbf{2}$ & 7.22 & $7.22 \%$ \\
$\mathbf{3}$ & 8.09 & $8.09 \%$ \\
\hline
\end{tabular}

Sargassum sp. extract different from the yield of $S$. filipendula extract with ethanol solvent in the other that is $1.69 \pm 0.159 \%$ [22]. The use of methanol solvents was more effective in the extraction of red algae Kappaphycus alvarezii and Eucheuma denticullatum than ethanol, which had a lower polarity level [23]. The difference in extract yield depends on the natural conditions of the sample, the extraction method, the particle size of the sample, the conditions and the extraction time, and the comparison of the sample with the solvent [24].

\section{Phytochemical screening}

Phytochemical data shows the chemical compositions in constituents of the sargassum extracts. The results of the phytochemical evaluation showed in Table 2. Phytochemical testing is necessary because it aims to determine the right type of secondary metabolic components in various plants, such as Sargassum sp. [25].

Table 2. Chemical compositions in Sargassum sp. extract

\begin{tabular}{cc}
\hline Constituents & Result \\
\hline Flavonoids & + \\
Alkaloids & - \\
Triterpenes & + \\
Saponins & + \\
Tannins & + \\
\hline
\end{tabular}

The phytochemical screening on Sargassum sp. showed the existence of compounds of Flavonoids, Triterpenes, Saponins, and Tannins. Alkaloids were absent in this seaweed. These plants contain essential phytochemical constituents and have various potential biological activities [26]. Phytochemical results of the current work revealed that these edible seaweeds could be potential candidates in the field of drug development.

\section{Hematological Analysis Result Total Erythrocyte Count}

The erythrocyte count of healthy fish (positive control) showed a mean value of $6.65 \times 10^{6} . \mathrm{mm}^{-3}$, and the exposed fish by pesticide without extract treatment (negative control) showed a mean value of $1.67 \times 10^{6} . \mathrm{mm}^{-3}$. The sargassum extract treatment to exposed fishes by methomyl-based pesticide with concentration A (25 ppm), B (50 ppm), C (100 ppm), and D (200 ppm) showed mean value of total erythrocyte count as 1.67, $1.69,3.00$, and $5.30 \times 10^{6} . \mathrm{mm}^{-3}$, respectively. The values mentioned in Figure 1 showed a significant increase when compared to the negative control.

According to figure 1, treatments fed with the algae extract exhibited significant increases in the WBC count. The increased concentration of extract treatment is directly proportional to the increase of erythrocyte cells. The erythrocyte 
count is an essential indicator of the internal and external environment of animals, where exposure to chemical pollutants can induce either increases or decreases in hematological levels [27].

The use of immunostimulants such as algae extract will be improving the immune system in fish. The fish immune system reflects the role of dietary supplements in boosting immunity because of specific characteristics, including a more efficient non-specific vs. specific immunity compared to those of warm-blooded animals [28]. Due to increased resistance of fish against environmental stress and pathogens [29], the use of immunostimulants is a widely examined approach to increase production $[30,31]$ in intensive and ultra-intensive rearing conditions.

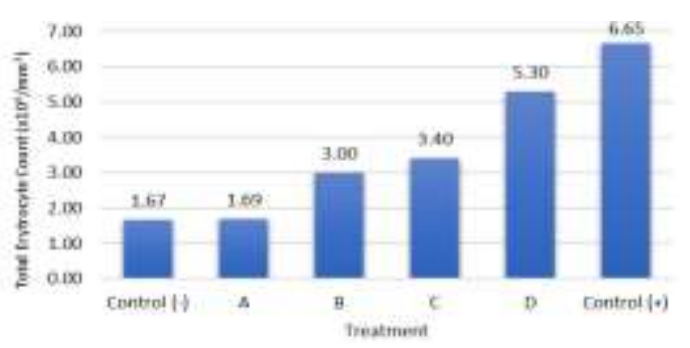

Figure 1. The Total Erythrocyte Count of Tilapia

\section{Micronuclei assay}

The Micronuclei assay in fish erythrocyte is widely used for genotoxicity assessment of marine and freshwater organisms. The frequencies of micronuclei formation at negative control (exposed fish without extract treatment) were significantly $(p<0.05)$ higher than the positive control (healthy fish) at treated groups. The genotoxicity of pesticides on fish in the present study was found in peripheral blood erythrocytes [6]. The micronuclei test is a sensitive assay to evaluate genotoxic compounds present in fish [32]. Peripheral blood erythrocytes (Fig. 2) of fish were for most of the micronuclei surveys, that carried out in peripheral blood erythrocytes of fish [33,34].

The micronuclei assay of tilapia fish during the research shown in Figure 3. The exposure of methomyl-based pesticide (control negative) indicates the formation of micronuclei $318.33 \%$. The increased concentration of extract treatment is directly proportional to the decrease of micronuclei. It means that sargassum extract can reduce the genotoxic effect on exposed tilapia by methomyl-based pesticides. Marine algae extract proved to be a powerful anti genotoxicant, which is primarily due to the combined role of phenolics and flavonoids [14].

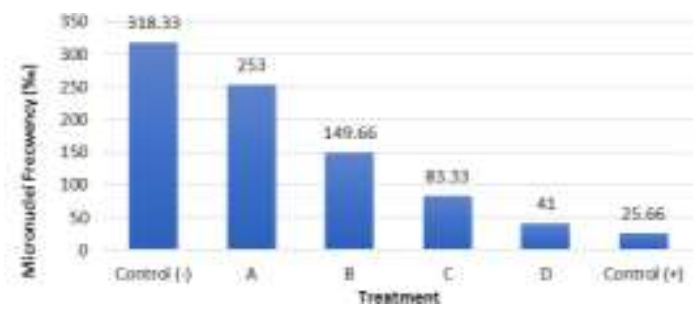

Figure 2. Micronuclei assay test in erythrocyte of tilapia

Dietary flavonoids have protective effects against DNA damage induced by different genotoxic agents. Flavonoids exert their genoprotections by reducing oxidative stress and modulation of enzymes responsible for bioactive of genotoxic agents and detoxification of their reactive metabolites [35]. Results showed that the best concentration of Sargassum sp. extract that can reduce genotoxic was D (200 ppm).

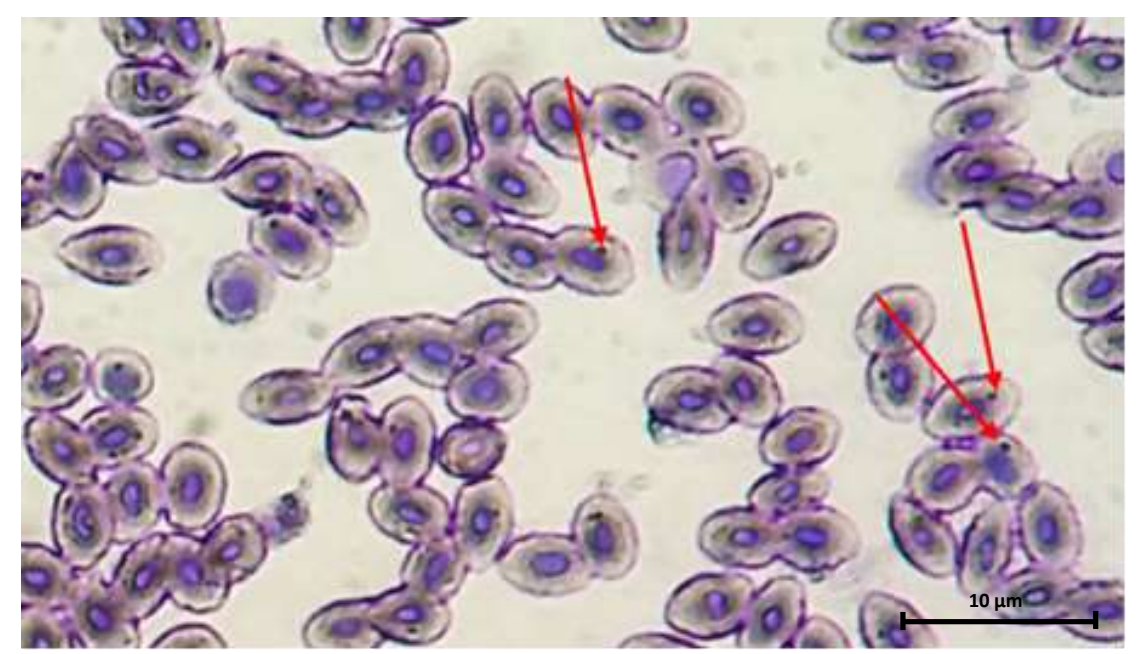

Figure 3. The micronuclei in erythrocyte cell (red arrows) 


\section{CONCLUSION}

The exposure of methomyl-based pesticides in the concentration of $4.015 \mathrm{ppm}$ indicates the formation of micronuclei of $318.33 \%$. The increased concentration of extract treatment is directly proportional to the decrease of micronuclei. It means that sargassum extract can reduce the genotoxic effect on exposed tilapia by methomyl-based pesticides. The best concentration of Sargassum sp. extract that can reduce genotoxic was D (200 ppm).

\section{REFERENCES}

[1] Sailaja, N., M. Chandrasekhar, P.V. Rekhadevi. 2006. Genotoxic evaluation of workers employed in pesticide production. Mutat. Res. 609.74-80

[2] WHO. 1996. Methomyl environmental health criteria 178. World Health Organization. Geneva.

[3] Meng, S.L., J.Z. Chen, G.H. Hu, C. Song, L.M. Fan, L.P. Qiu, P. Xu. 2014. Effects of chronic exposure of methomyl on the antioxidant system in the liver of Nile Tilapia (Oreochromis niloticus). Ecotoxicol. Environ. Saf. 101. 1-6.

[4] Supriyono, E. 2005. Studi toksisitas insektisida triklorfon terhadap ikan Nila (O. niloticus). Bogor Agricultural University. Bogor.

[5] Li, H., H. Jiang, X. Gao, X. Wang, W. Qu, R. Lin, J. Chen. 2008. Acute toxicity of the pesticide methomyl on the Topmouth Gudgeon (Pseudorasbora parva): mortality and effects on four biomarkers. Fish Physiol. Biochem. 34(3). 209-216.

[6] Islamy, R. A., Yanuhar, U., \& Hertika, A. M. S. 2017. Assessing the genotoxic potentials of methomyl-based pesticide in Tilapia (Oreochromis niloticus) using micronucleus assay. J. Exp. Life Sci. 7(2), 88-93.

[7] Datta, S., D. Ghosh, D.R. Saha, S. Bhattacharaya, S. Mazumder. 2009. Chronic exposure to low concentration of arsenic is immunotoxic to fish: Role of head kidney macrophages as biomarkers of arsenic toxicity to Clarias batrachus. Aquat. Toxicol. 92. 86-94.

[8] Da Rocha, C.A.M., L.A. da Cunha, R.H.S. Pinheiro, M.O. Bahia, R.M.R. Burbano. 2011. Studies of micronuclei and other nuclear abnormalities in red blood cells of Colossoma macropomum exposed to methyl mercury. Gen. Mol. Biol. 34. 694697.
[9] Fazio, F., C. Faggio, S. Marafioti, A. Torre, M. Sanfilippo, G. Piccione. 2013. Effect of water quality on hematological and biochemical parameters of Gobius niger caught in Faro lake (Sicily). Iran J. Fish Sci. 12. 219-231.

[10] Fazio, F., S. Marafioti, A. Torre, M. Sanfilippo, M. Panzera, C. Faggio. 2013. Hematological and serum protein profiles of Mugil cephalus: effect of two different habitats. Ichthyol. Res. 60. 36-42.

[11] Al-Sabti., K, C.D. Metcalfe. 1995. Fish micronuclei for assessing genotoxicity in water. Mutat. Res. 343. 121-135.

[12] Mohammed, K.P., A. Aarey, S. Tamkeen, P. Jahan. 2015. Mutation Research/genetic toxicology and environmental mutagenesis. Mutat. Res. 777. 29-32.

[13] Gamal-Eldeen, A.M., M.A. Abo-Zeid, E.F. Ahmed. 2013. Anti-genotoxic effect of the Sargassum dentifolium extracts: Prevention of chromosomal aberrations, micronuclei, and DNA fragmentation. Exp. Toxicol. Pathol. 65(1-2). 27-34.

[14] Ali, M.S. 2017. Anti genotoxic effect of TiO2 nanoparticle biosynthesized from Sargassum polycystum - a marine macroalgae. J. Nanomed. Res. 5(4). 1-6.

[15] Kamba, A.S., L.G. Hassan. 2010. Phytochemical screening and antimicrobial activities of Euphorbia balsamifera leaves, stems and root against some pathogenic microorganisms. Afr. J. Pharm. Pharmacol. 4. 645-652.

[16] Cahyaningrum, K., A. Husni, S.A.Budhiyanti. 2016. Antioxidant activity of brown seaweed (Sargassum polycystum) extracts. Jurnal Agritech. 36(2). 137-144.

[17] Rosenfeld, G. 1947. Corante pancrômico para hematologia e citologia clínica. Nova combinação dos components do MayGrunwald e do Giemsa num só corante de emprego rápido. Mem. Inst. But. 20. 329334.

[18] Sebastião, F.A., D. Nomura, R. Sakabe, F. Pilarski. 2011. Hematology and productive performance of nile tilapia (Oreochromis niloticus) naturally infected with Flavobacterium columnare. Braz. J. Microbiol. 42(1). 282-289.

[19] Osman, G.M., M. Koutb, A.H. Sayed. 2010. Use of hematological parameters to assess the efficiency of quince (Cydonia oblonga Miller) leaf extract in alleviation of the effect of ultraviolet -A radiation on African 
catfish Clarias gariepinus. J. Photoch. Photobio. B. 99. 1-8.

[20] Güner, U., F.D. Muranlı. 2011. Micronucleus test, nuclear abnormalities and accumulation of $\mathrm{Cu}$ and $\mathrm{Cd}$ on Gambusia affinis (Baird and Girard, 1853). Turk. J. Fish Aquat. Sci. 11. 615-622.

[21] Betancur, I.P., J.A. Palacio Baena, M.C. Guerrero. 2009. Micronuclei test application to wild tropical ichthyic species common in two lentic environments of the low zones in Colombia. Actual Biol. 31. 6777.

[22] Bambang, B.S., S. Kumalaningsih, W. Susinggih, Hardoko. 2013. Polyphenol content and antioxidant activities of crude extract from brown algae by various solvents. J. Life Sci. Biomed. 3(6). 439-443.

[23] Wijayanto, D.B. 2010. Uji aktivitas antibakteri ekstrak rumput laut Kappaphycus alvarezii dan Eucheuma denticullatum terhadap bakteri Aeromonas hydrophila dan Vibrio harveyii. Jurnal Kelautan. 3(1). 1-17.

[24] Harborne, J.B. 1987. Phytochemical methods, $2^{\text {nd }}$ Ed. Padmawinata, K., I. Soediro (Transl). Bandung Institute of TechnologyBandung.

[25] Batra, P., A.K. Sharma. 2013. Anti-cancer potential of flavonoids: recent trends and future perspectives. 3 Biotech. 3(6). 439459.

[26] Mehdinezhad, N., A. Ghannadi, A. Yegdaneh. 2016. Phytochemical and biological evaluation of some Sargassum species from Persian Gulf. Res. Pharm. Sci. 11(3). 243-249.

[27] Parveen, N., F. Firdaus, G.G.H.A. Shadab. 2013. Assessment of micronuclei and chromosomal aberrations in Channa punctatu exposed to lead nitrate. Adv. Sci. Eng. Med. 5(7). 683-687.

[28] Zeraatpisheh, F., F. Firouzbakhsh, K.J.Khalili. 2018. Effects of the macroalga Sargassum angustifolium hot water extract on hematological parameters and immune responses in rainbow trout (Oncohrynchus mykiss) infected with Yersinia rukeri. J. Appl. Phycol. 30(3). 2029-2037.

[29] Li, G., Y. Guo, D. Zhao, P. Qian, J. Sun. 2006. Effects of levamisole on the immune response and disease resistance of Clarias fuscus. Aquaculture. 253. 61-69.

[30] Immanuel, G.V., V. Vincybai. 2004. Effect of butanolic extracts from terrestrial herbs and seaweeds on the survival, growth and pathogen (Vibrio parahaemolyticus) load on shrimp Penaeus indicus juveniles. Aquaculture. 236. 53-65.

[31] Marian, M.P. 2004. Growth and immune response of juvenile greasy groupers (Epinephelus tauvina) fed with herbal antibacterial active principle supplemented diets against Vibrio harveyi infections. Aquaculture. 237. 9-20.

[32] Bolognesi, C., E. Perrone, P. Roggieri, D.M. Pampanin, A. Sciutto. 2006. Assessment of micronuclei induction in peripheral erythrocytes of fish exposed to xenobiotics under controlled conditions. Aquat. Toxicol. 78 (Suppl 1). S93-S98.

[33] De Flora, S., L. Viganò, F. D'Agostini, A. Camoirano, M. Bagnasco, C. Bennicelli, F. Melodia, A. Arillo. 1993. Multiple genotoxicity biomarkers in fish exposed in situ to polluted river water. Mutat. Res. 319. 167-177.

[34] Minissi, S., E. Ciccotti, M. Rizzoni. 1996. Micronucleus test in erythrocytes of Barbus plebejus (Teleostei pisces) from two natural environments: a bioassay for the in situ detection of mutagens in freshwater. Mutat. Res. 367. 245-251.

[35] Luca, V.S., A. Miron, A.C. Aprotosoaie. 2016. The antigenotoxic potential of dietary flavonoids. Phytochem. Rev. 15(4). 591-625. 